\title{
ANALISA KELAYAKAN USAHA DAN STRATEGI PEMASARAN KERIPIK OLAHAN TALAS DI DESA TEKAD-LAMPUNG
}

\author{
Mucklas Kamseno'), laily Maknin ${ }^{2)}$ \\ ${ }^{1)}$ Mahasiswa Program Studi Teknik Industri, Fakultas Teknik, Universitas Pamulang \\ ${ }^{2)}$ Dosen Fakultas Teknik Program Studi Teknik Industri, Universitas Pamulang \\ Mucklas_k@yahoo.com
}

\begin{abstract}
ABSTRAK
Di Indonesia banyak daerah yang menjadikan sektor pertanian sebagai mata pencaharian mereka. Bermacam-macam hasil bumi dan pertanian yang mereka tanam, dimana hal tersebut didukung penuh oleh Pemerintah. Kabupaten Tanggamus adalah salah satunya, Kabupaten Tanggamus memiliki potensi sumber daya alam yang potensial untuk dikembangkan, salah satunya yaitu sektor pertanian. Bermacam hasil bumi yang dihasilkan dari pertanian yang ada di Kabupaten Tanggamu, salah satunya adalah Talas. Usaha Industri kecil keripik talas di Kabupaten Tanggamus layak untuk dilakukan investasi dan menjalankan operasional perusahaan. Break Even Point (Titik Impas) Unit dari usaha keripik olahan talas yang di desa Tekad Lampung Yaitu 2 bungkus, Sedangkan Untuk BEP uang yang didapat yaitu Rp. 12.121. Stratregi pemasaran yang tepat untuk usaha keripik olahan talas di desa Tekad Lampung dengan metode SWOT, Salah satu cara promosi yang dapat dilakukan oleh UKM Top Talassa adalah dengan memanfaatkan teknologi yang ada saat ini, seperti dengan menggunakan internet dan memakai media sosial yang banyak digemari oleh masyarakat khususnya untuk kalangan muda seperti twitter, instagram, line, blog serta media sosial lainnya. Memang UKM Top Talassa telah memiliki media sosial facebook. Selain itu, perlu juga penyebaran brosur, spanduk atau bahkan ikut hadir dalam kegiatan-kegiatan bazaar maupun event lainnya yang dapat dimanfaatkan oleh UKM Top Talassa untuk mempromosikan produk mereka secara langsung kepada konsumen.
\end{abstract}

Kata kunci : SWOT, Analisa Kelayakan, Break Even Point

\section{PENDAHULUAN}

Kabupaten Tanggamus memiliki potensi sumber daya alam yang potensial untuk dikembangkan, salah satunya yaitu sektor pertanian. Daerah Tanggamus yang subur sangat cocok untuk dijadikan lahan pertanian. Bermacam hasil bumi yang dihasilkan dari pertanian yang ada di Kabupaten Tanggamu, salah satunya adalah Talas.

Keripik Talas selalu menjadi favorit di semua kalangan tanpa memandang usia. Kesadaran ini membuat para pelaku usaha melihat, bahwa peluang usaha keripik talas masih sangat terbuka lebar. Usaha keripik talas masih memiliki potensi yang sangat bagus ke depannya. Oleh karena itulah, hampir di semua daerah memanfaatkan peluang ini, termasuk di Kabupaten Tanggamus. Atas dasar inilah muncul usaha keripik talas di desa Tekad, Lampung. Karena bahan baku berupa talas di desa tersebut mudah didapat, seingga salah satu usaha di desa
Tekad yang maju adalah dengan memanfaatkan talas untuk dijadikan keripik.

Seperti diketahui sebelumnya, untuk menilai suatu usaha layak dijalankan atau tidak perlu dilakukannya sebuah studi kelayakan. Oleh karena itu, dalam tugas akhir ini, penulis mengangkat Judul “Analisa Kelayakan Usaha dan Strategi Pemasaran Keripik Olahan Talas Di Desa Tekad-Lampung”, dengan harapan dapat membantu pemilik usaha di desa Tekad agar dapat menilai serta mengembangkan usahanya menjadi lebih besar, hingga di waktu mendatang.

\section{DASAR TEORI}

\section{A. Sektor Pertanian/Produk Pertanian}

Struktur perekonomian Indonesia tentang bagaimana arah kebijakan perekonomian Indonesia merupakan isu menarik. Gagasan mengenai langkah-langkah perekonomian Indonesia menuju era industrialisasi dengan 
mempertimbangkan usaha mempersempit jurang ketimpangan sosial dan pemberdayaan daerah, sehingga terjadi pemerataan kesejahteraan kiranya perlu kita evaluasi kembali sesuai dengan konteks kekinian dan tantangan perekonomian Indonesia di era globalisasi (Firmanzah, 2010).

\section{B. Pengertian Usaha Kecil dan Menengah}

Pengertian mengenai UKM (Usaha Kecil Menengah) tidak selalu sama, tergantung konsep yang digunakan. Dalam konsep tersebut mencakup sedikitnya dua aspek yaitu aspek penyerapan tenaga kerja dan aspek pengelompokan perusahaan ditinjau dari jumlah tenaga kerja yang diserap dalam kelompok perusahaan tersebut. Usaha kecil dioperasikan dan dimiliki secara independen, tidak dominan dalam daerahnya dan tidak mengunakan praktek\#praktek inovatif. Tapi usaha yang bersifat kewirausahaan adalah usaha yang pada awalnya bertujuan untuk tumbuh dan menguntungkan serta dapat dikarakteristikkan dengan praktekpraktek inovasi strategis (Maharani,2008:105)

\section{Talas}

Tanaman Talas merupakan tumbuhan asli daerah tropis. Tanaman ini mempunyai beberapa nama umum yaitu Taro, Old Cocoyam, 'Dasheen' dan 'Eddoe', bebrapa negara dikenal dengan nama lain seperti: Abalong (Filipina), Taioba (Bazil), Arvi (India), Keladi (Malaysa), Satoimo (Jepang), Tayoba (Spanyol) dan Yu-tao (China). Berdasarkan hasil ekspedisi seorang ahli botani soviet yang bernama Nikolai Ivanovich Vavilov, menunjukkan bahwa sentrum asal tanaman talas adalah dataran Cina dan india dengan ditemukannya plasma nutfah Colocasiaantipuorum. Namun, terdapat literatur lain yang menyebutkan bahwa asal-usul tanaman talas terdapat diberbagai daerah beriklim tropis misalnya di malaysia ditemukan talas Dasheen(Colocasia Gigantea Hook,f), di Indonesia ditemukan Talas Bogor (Colocasia Esculenta L. Schott), dan di Amerika Tengah menyebar tanaman Kimpul (Xanthosoma violaceum Schott). (Rukmana, 2006).

\section{Pengertian Produksi}

Produksi adalah kegiatan yang mentransformasikan masukan (Input) menjadi keluaran (Output), tercakup semua aktifitas atau kegiatan yang menghasilkan barang atau jasa, serta kegiatan-kegiatan lain yang mendukung atau menunjang usaha untuk menghasilkan produk tersebut yang berupa barang-barang atau jasa. (Sofjan Assari, 2008:17

\section{E. Tujuan Manajemen Keuangan (Finansial)}

Menurut Brigham dan Houston (2010:132) yang diterjemahakan oleh Yulianto tujuan manajemen keuangan yaitu memaksimalkan kekayaan pemegang saham dalam jangka panjang, tetapi bukan untuk memaksimalkan ukuran-ukuran akuntansi seperti laba bersih atau EPS.

BEP merupakan singkatan dari Break Even Point.Break Even Pointadalah suatu keadaan dimana perusahaan yang pendapatanpenjualannya sama dengan total jumlah biayanya atau besarnya kontribusi margin, sama dengan total biaya tetap, dengan katalain perusahaan ini tidak untung dan tidak rugi. (Bustam, 2006:208).

$$
\begin{array}{|ll|}
\hline \text { BEP Uang } & =\frac{F C}{1-\frac{V C}{P}} \\
\hline \text { BEP Unit } & =\frac{F C}{P-V C} \\
\hline \text { Dimana: } & \\
\text { FC } & =\text { Biaya tetap (Variabel Cost) } \\
\text { P } & =\text { Harga } \\
\text { VC } & =\text { Biaya variabel perunit }
\end{array}
$$

\section{F. Definisi Pemasaran}

Pemasaran adalah suatu fungsi organisasi dan serangkaian proses untuk menciptakan, mengomunikasikan dan memberikan nilai kepada pelanggan dan untuk mengelola hubungan pelanggan dengan cara yang menguntungkan organisasi dan para pemangku kepentingannya. (Kotler, 2009).

\section{G. Definisi SWOT}

SWOT adalah akronim untuk kekuatan (Strenghts), kelemahan (Weakness), peluang (Opportunities), dan ancaman (Threats) dari lingkungan eksternal perusahaan.

Menurut David (Fred R. David, 2008,8), Semua organisasi memiliki kekuatan dan kelemahan dalam area fungsional bisnis. Tidak ada perusahaan yang sama kuatnya atau lemahnya dalam semua area bisnis. 
Strategi perusahaan secara efektif mengambil keuntungan dari peluang yang ada saat ini dan meminimalkan efek yang mungkin muncul dari ancaman eksternal,

\begin{tabular}{|l|l|l|l|}
\hline \multicolumn{1}{|c|}{ PELCANG } & BOBOT & RATING & SKOR \\
\hline Peluang 1 & & & \\
\hline Peluang 2 & & & \\
\hline Peluang 3 & & & \\
\hline Peluang 4 & & & \\
\hline \multicolumn{1}{|c|}{ ANCAMAX } & BOBOT & RATIXG & SKOR \\
\hline Ancaman 1 & & & \\
\hline Ancaman2 & & & \\
\hline Ancaman 3 & & & \\
\hline Ancaman 4 & & & \\
\hline Total Skor Pembobotan & & & \\
\hline
\end{tabular}

(Sumber:David 2006)

Gambar 1 Eksternal Factor Evaluation (EFE)

\section{H. Marix SWOT}

Menurut Rangkuti (2006), Matriks SWOT dapat menggambarkan secara jelas bagaimana peluang dan ancaman eksternal yang dihadapi perusahaan dapat disesuaikan dengan kekuatan dankelemahan yang dimilikinya. Matriks ini dapat menghasilkan empat set kemungkinan altenatif strategis.

\begin{tabular}{|l|l|l|}
\hline EFAS & Kekuatan (Sirength) & Kelemahan (Weakness) \\
\hline Peluang (Opportumity) & $\begin{array}{c}\text { STRATEGI SO } \\
\text { Ciptakan strategi yang } \\
\text { menggunakan kekuatan } \\
\text { untuk memanfaatkan } \\
\text { peluang }\end{array}$ & $\begin{array}{l}\text { STRATEGI WO } \\
\text { Ciptakan strategi yang } \\
\text { meminimalkan kelemahan } \\
\text { untuk memanfaatkan } \\
\text { peluang }\end{array}$ \\
\hline Ancaman (Threats) & $\begin{array}{l}\text { STRATEGI ST } \\
\text { Ciptakan strategi yang } \\
\text { menggunakan keknatan } \\
\text { untuk mengatasi ancammn }\end{array}$ & $\begin{array}{l}\text { STRATEGI WT } \\
\text { Ciptakan strategi yang } \\
\text { meminimalkan kelemahan } \\
\text { dan menghindari ancaman }\end{array}$ \\
\hline
\end{tabular}

(Sumber: Rangkuti, 2009)

Gambar 2Matrix SWOT

\section{Kerangka Fikir}

Adapun kerangka pikir penelitian ini digambarkan dengan diagram alur

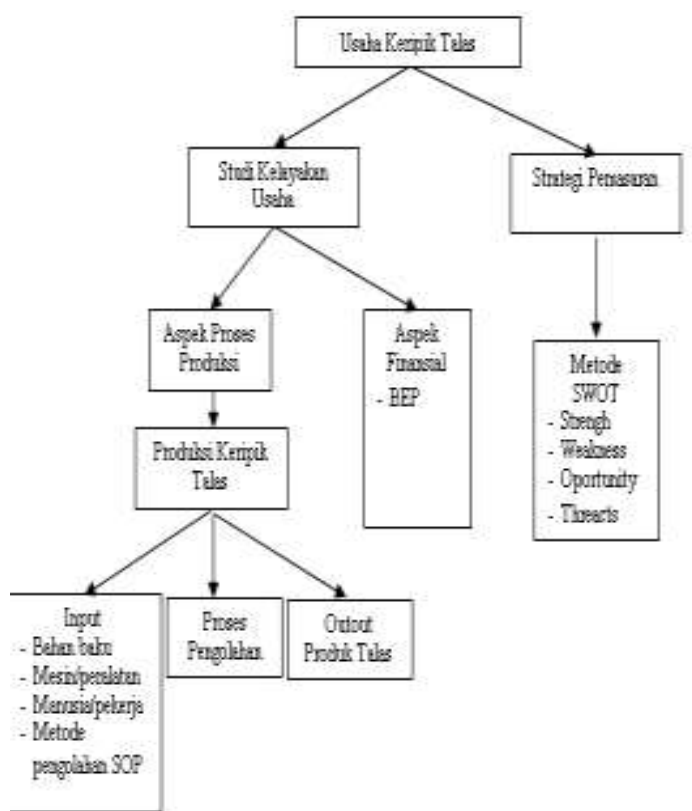

(Sumber: Data Olahan Sendiri)

Gambar 3 Kerangka Pikir

\section{METODE DAN TEKNIK PENGUKURAN}

Kronologi prosedur yang dilakukan seorang peneliti dalam karya penelitiannya dan bukan sekedar urutan apa yang mesti dilalui. Alur penelitian lebih merupakan strukturisasi atau hubungan metodologi yang berkesinambungan. Adapun tahapan metodologi penelitian.

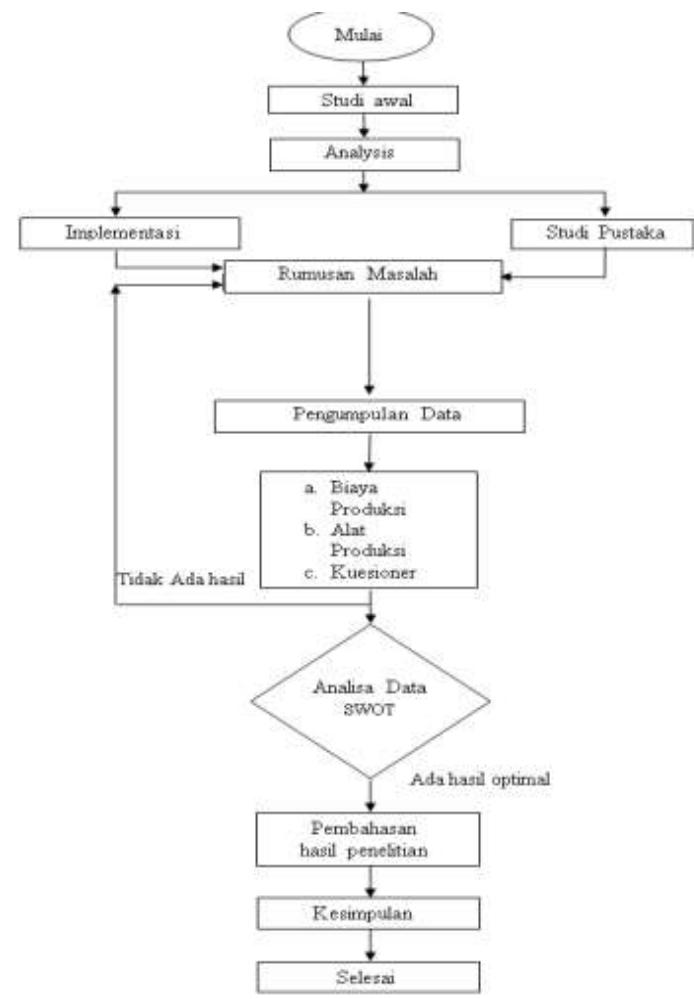

(Sumber:: Data Olahan Sendiri)

Gambar 4 Flowchart Metodologi Penelitian 


\section{HASIL DAN PEMBAHASAN}

\section{A. Sejarah Perusahaan}

Usaha kecil menengah (UKM) Top Talassadidirikan oleh Mucklas Kamseno, seorang mahasiswa sebuah perguruan tinggi swasta di Tangerang Selatan pada tanggal 4 Maret 2015. Berawal dari ketidak sengajaan untuk berinovasi sekaligus berinvestasi, Pemilik yang pada saat itu melihat banyaknya tanaman umbi talas di kebun sendiri yang tidak dimanfaatkan dan kebanyakan hanya diambil daunnya saja untuk makanan ikan, kemudian saya merekrut beberapa tetangga dan teman-teman di sekitar lingkungan tempat tinggal untuk bekerja sama. Dari modal yang sedikit dan serba sederhana inilah usaha home industri/usaha kecil menengah (UKM) Top Talassaberhasil didirikan. Bermodalkan Rp. 5.000.000,00 dan Top Talassamulai diperkenalkan kemasyarakat sekitar.

\section{B. Lokasi Perusahaan}

Usaha Kecil Menengah Top Talassa, berlokasi di RT. 03 RW. 03 Dusun Tekad, Desa Tekad, Kecamatan Pulaupanggung, Kabupaten Tanggamus. Lampung. Kabupaten Tanggamus merupakan salah satu kabupaten di Propinsi Lampung. Indonesia. Ibu kota kabupaten Tanggamus terletak di Kota Agung Pusat. Kabupaten Tanggamus diresmikan berdasarkan Undang-Undang Nomor 2 Tahun 1997, tanggal 21 Maret 1997. Kabupaten ini memiliki luas wilayah $2.731,61 \mathrm{~km}^{2}$ dan berpenduduk sebanyak 536.613 jiwa dengan kepadatan penduduk 178 jiwa/ $/ \mathrm{km}^{2}$. Nama Kabupaten Tanggamus diambil dari nama Gunung Tanggamus yang berdiri tegak tepat di jantung Kabupaten Tanggamus.

\section{SSTRUKTUR ORGANISASI}

Struktur organisasi UKM Top Talasa

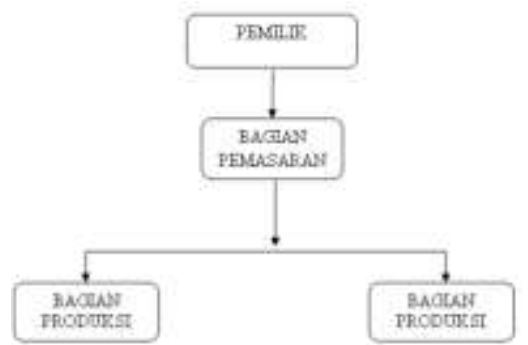

(Sumber; Hasil Olahan Sendiri)

Gambar 5 Struktur Organisasi

\section{Proses Produksi}

Produksi keripik talasdiUKM Top Talassa semua prosesnya menggunakan tenaga manusia dan alat tradisional. Keripik talas terdiri dari 2 (dua) cita rasa yaitu rasa balado dan gurih original. Adapun tahapan-tahapan proses pembuatan keripik talas rasa balado di UKM Top Talasa dapat dilihat pada Gambar di bawah ini.

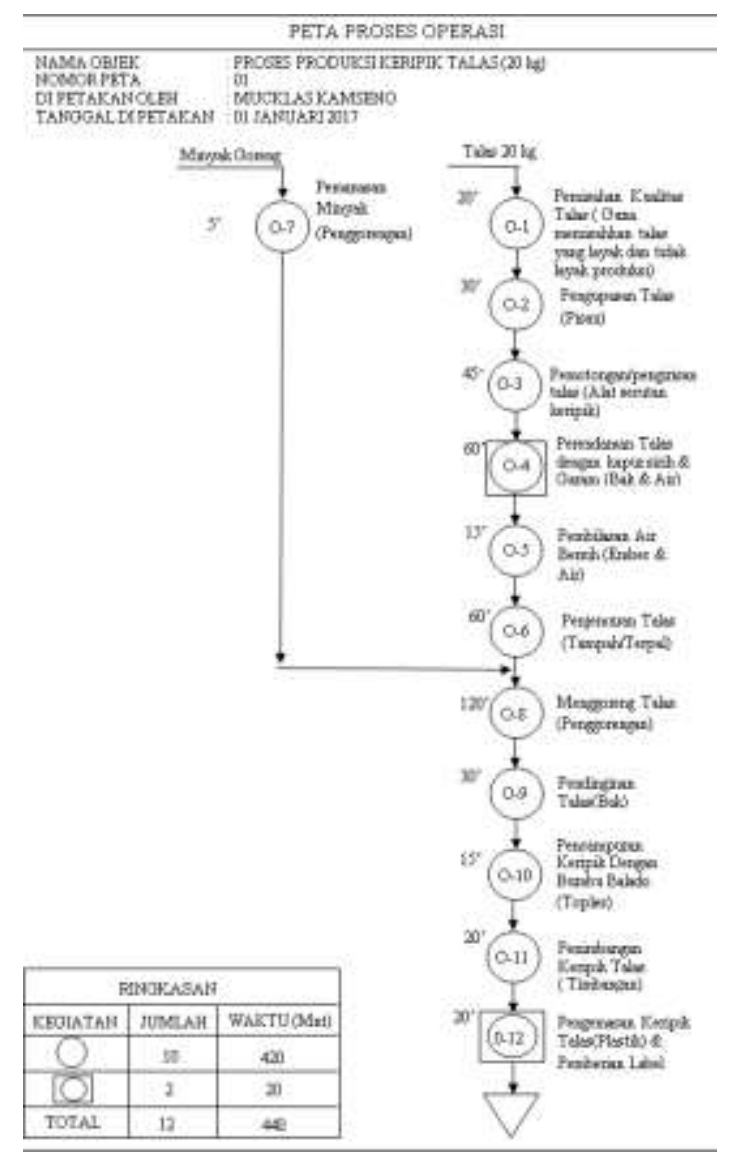

Sumber: Hasil Olahan Sendiri)

Gambar 6 Peta Proses Operasi Krepik Talas

\section{E. Biaya Bahan Baku}

Berikut ini adalah data yang berkaitan dengan biaya bahan baku, akan disajikan dalam Tabel di bawah tentang biaya bahan baku untuk memproduksi keripik talas.

\section{F. Biaya Tenaga Kerja Langsung}

Berikut biaya kerja langsung di UKM top talassa memperkerjakan tenaga kerja langsung sebanyak 3 orang. 
Tabel 1 Biaya Tenaga Kerja langsung

\begin{tabular}{|c|c|c|c|c|}
\hline Jenis Pekrajaan & $\begin{array}{l}\text { Jumlah } \\
\text { Pelverja }\end{array}$ & $\begin{array}{c}\text { Cpah } \\
\text { Peroray }\end{array}$ & $\begin{array}{c}\text { Jumlah Hari } \\
\text { Kerija }\end{array}$ & Tpah Perbari \\
\hline Peribuaton keripik tals & 20 reng & 30.00 & 1 & 60.00 \\
\hline Pemastran & 1 Cong & $\begin{array}{l}50.000 \\
20.000\end{array}$ & $\begin{array}{l}1 \\
1\end{array}$ & $\begin{array}{l}50.000 \\
20.000\end{array}$ \\
\hline \multicolumn{4}{|c|}{ Iotal } & 130.600 \\
\hline
\end{tabular}

Sumber: Hasil Olahan Sendiri)

\section{G. Biaya Front Of Hose (FOH)}

Berikut ini adalah data yang berkaitan dengan biaya Front Of Hose (FOH).

Tabel 2 Biaya Front Of Hose (FOH)

\begin{tabular}{|c|l|c|c|c|c|}
\hline No & \multicolumn{1}{|c|}{ Nama } & Satuan & $\begin{array}{c}\text { Harga } \\
(\mathbf{R p})\end{array}$ & Qty & $\begin{array}{c}\text { Jumlah } \\
(\mathbf{R p})\end{array}$ \\
\hline 1. & $\begin{array}{l}\text { Gas ukuran 3 } \\
\mathrm{kg}\end{array}$ & Tabung & 21.000 & $3 / 4$ & 15.750 \\
\hline 2. & $\begin{array}{l}\text { Plastik } \\
\text { Kemasan }\end{array}$ & pcs & 100 & 80 & 8.000 \\
\hline 3. & Kertas label & lbr & 250 & 9 & 2.250 \\
\hline 4. & $\begin{array}{l}\text { Listrik (Sealer, } \\
\text { Pompa Air, } \\
\text { Lampu) Kwh }\end{array}$ & 1.467 & 4,03 & 5.950 \\
\hline \multicolumn{4}{|c|}{ Total } & & $\mathbf{3 1 . 9 5 0}$ \\
\hline
\end{tabular}

(Sumber: Hasil Olahan Sendiri)

Berikut perhitungan penggunaan listrik UKM Top Talasa

Harga Listrik = Rp. 1467

/Kwh

a. Sealer

b. Pompa Air

$=10,8 \mathrm{kwh}$

$=90 \mathrm{kwh}$

c. Lampu

$=15,12 \mathrm{kwh}$

Total $120,92 \mathrm{kwh} / \mathrm{bulan}$

$$
\frac{1}{30} \times 120,92=4,03
$$

$$
\begin{aligned}
\text { Biaya Listrik/hari } & =4,03 \times 1467 \\
& =5912 \\
& =\operatorname{Rp} .5 .950
\end{aligned}
$$

\section{H. Rancangan Biaya Produksi}

Adalah rancangan modal/produksi harian

\begin{tabular}{|c|c|c|c|c|c|}
\hline $\begin{array}{l}\mathbf{N} \\
\mathbf{0}\end{array}$ & Uraian & Satuan & $\begin{array}{c}\text { Harga } \\
\text { (Rp) }\end{array}$ & $\begin{array}{l}\mathbf{Q t} \\
\mathbf{y}\end{array}$ & $\begin{array}{c}\text { Jumlah } \\
\text { (Rp) }\end{array}$ \\
\hline \multirow[t]{4}{*}{1} & Bahan Baku & & & & \\
\hline & a. Talas & $\mathrm{Kg}$ & 3.000 & 20 & 60.000 \\
\hline & $\begin{array}{ll}\text { b. } & \begin{array}{l}\text { Minyak } \\
\text { Goreng }\end{array}\end{array}$ & Liter & 13.000 & 5 & 65.000 \\
\hline & c. Kapur & Bks & & 1 & 4.000 \\
\hline
\end{tabular}
pembuatan keripik talas di UKM Top Talasa

\begin{tabular}{|c|c|c|c|c|c|}
\hline & Sirih & & 4.000 & & \\
\hline & d. Garam & $\mathrm{Kg}$ & 6.000 & $1 / 2$ & 3.000 \\
\hline & $\begin{array}{ll}\text { e. } & \begin{array}{l}\text { Bumbu } \\
\text { Balado }\end{array}\end{array}$ & $\mathrm{Kg}$ & 40.000 & $1 / 2$ & 20.000 \\
\hline & \multicolumn{3}{|c|}{ TOTAL } & & $\mathbf{1 5 2 . 0 0 0}$ \\
\hline \multirow[t]{4}{*}{$\begin{array}{l}2 \\
.\end{array}$} & $\begin{array}{l}\text { Upah Tenaga } \\
\text { Kerja }\end{array}$ & Orang & 50.000 & 1 & 50.000 \\
\hline & & Orang & 30.000 & 2 & 60.000 \\
\hline & Pemasaran & Hari & 20.000 & 1 & 20.000 \\
\hline & \multicolumn{3}{|c|}{ TOTAL } & & 130.000 \\
\hline \multirow[t]{6}{*}{3} & $\begin{array}{l}\text { Biaya Oper } \\
\text { Head (Front } \\
\text { Of Hose) } \\
\end{array}$ & & & & \\
\hline & a. Gas & 3 & 21.000 & $3 / 4$ & 15.750 \\
\hline & $\begin{array}{ll}\text { b. } & \text { Plastik } \\
& \text { Kemasan } \\
\end{array}$ & pes & 100 & 80 & 8.000 \\
\hline & $\begin{array}{ll}\text { c. } & \begin{array}{l}\text { Kertas } \\
\text { label }\end{array} \\
\end{array}$ & lbr & 250 & 9 & 2.250 \\
\hline & $\begin{array}{ll}\text { d. } & \text { Listrik } \\
& \text { (Lampu,sr } \\
& \text { aler, } \\
& \text { pompa air) } \\
\end{array}$ & kwh & 1.467 & $\begin{array}{c}4,0 \\
3\end{array}$ & 5.950 \\
\hline & \multicolumn{3}{|c|}{ TOTAL } & & 31.950 \\
\hline \multicolumn{4}{|c|}{ TOTAL KESELURUHAN } & & 313.950 \\
\hline
\end{tabular}

Tabel 3 Rancangan Modal Produksi Keripik Talasi/Hari
(Sumber: Data Olahan Sendiri)

\section{Biaya Fasilitas Produksi / Alat}

Berikut ini adalah data yang berkaitan denganbiaya fasilitas produksi.alat.

Tabel 4 Biaya Fasilitas Produksi/Alat

\begin{tabular}{|c|l|c|l|l|}
\hline No & Nama Barang & Volume & $\begin{array}{c}\text { Hatga } \\
\text { Satuan }\end{array}$ & Jumlah \\
\hline 1 & Kompor Gas & 1 Unit & 250.000 & 250.000 \\
\hline 2 & Tabung Gas & 1 Unit & 150.000 & 150.000 \\
\hline 3 & Regulator & 1 Unit & 100.000 & 100.000 \\
\hline 4 & Ember & 2 Unit & 20.000 & 40.000 \\
\hline 5 & Penggorengan & 2 Unit & 100.000 & 200.000 \\
\hline 6 & Spatula & 2 Unit & 20.000 & 40.000 \\
\hline 7 & $\begin{array}{l}\text { Alat Potong } \\
\text { Talas }\end{array}$ & 2 Unit & 30.000 & 60.000 \\
\hline 8 & Serok & 2 Unit & 25.000 & 50.000 \\
\hline 9 & Baskom & 2 Unit & 30.000 & 60.000 \\
\hline 10 & Tampah & 20.000 & 40.000 \\
\hline 11 & Sealer & 1 Unit & 150.000 & 150.000 \\
\hline 12 & Pisau & 1 Unit & 10.000 & 20.000 \\
\hline 13 & Timbangan & 150.000 & 150.000 \\
\hline 14 & Lampu Unit & 65.000 & 65.000 \\
\hline \multicolumn{4}{|l|}{} & $\mathbf{1 . 3 7 5 . 0 0 0}$ \\
\hline
\end{tabular}

(Sumber: Hasil Olahan Sendiri)

\section{J. Kapasitas Produksi}

Kapasitas produksi keripik talas UKM Top Talasa perhari adalah:
1. Talas
$=20 \mathrm{~kg}$
2. Keripik talas
$=10 \mathrm{~kg}$
3. Berat isi kemasam
$=125$ gram
4. Kapasitas produksi keripik $=10.000$ gram
125 gram
$=80 \mathrm{bks} / \mathrm{hari}$ 


\section{K. Biaya tetap}

Biaya Penyusutan dalam Usaha Keripik Talas, tempat produksi keripik talas yaitu dapur rumah mengalami penyusutan dengan rincian sebagai berikut :
Luas Tanah
$=11 \times 33=363 \mathrm{M}^{2}$
Luas Bangunan

$$
=3 \times 5=15 \mathrm{M}^{2}
$$

Harga Bangunan Dapur per $\mathrm{M}^{2}=1.000 .000$

1. Penyusutan dapur

$=$ Rp.1.500.000/Tahun

2. Pajak

$=$ Rp. 300.000/tahun

Total

$$
\begin{array}{ll}
=\text { Rp. } & 1.800 .000 / \text { Tahan } \\
=\text { Rp. } & 150.000 \text { 'bulan } \\
=\text { Rp. } & 5000 / \text { hari }
\end{array}
$$

\section{Total Pendapatan}

Hasil pendapatan produksi keripik talas di UKM Top Talasa:

Produksi keripik talas tiap hari $=80$ bungkus

1. Biaya produksi $=$ Rp. $313.950+$ Rp. 5000

$$
\begin{aligned}
& =\text { Rp. } 318 \cdot 950: 80 \mathrm{bks} \\
& =\text { Rp. } 3986,87 \\
& =\text { Rp. } 4.000 / \mathrm{bks}
\end{aligned}
$$

2. Harga penjualan/ bungkus dengan estimasi keuntungan $50 \%$

$$
\begin{aligned}
& =(50 \% \times \text { biaya produksi })+\text { biaya produksi } \\
& =\left(\frac{50}{100} \times \text { Rp. } 4000\right)+\mathrm{Rp} .4 .000 \\
& =\mathrm{Rp} .2000+\mathrm{Rp} .4 .000 \\
& =\text { Rp. } 6000
\end{aligned}
$$

\section{Perhitungan Break Even Point (BEP)}

$$
\text { BEP Unit }=\frac{F C}{p-\frac{V C}{P}}
$$

$$
\text { BEP Uang }=\frac{F C}{1-\frac{V_{A}}{P}}
$$

\begin{tabular}{|c|c|c|c|c|}
\hline \multicolumn{5}{|c|}{ Talasa } \\
\hline No & Faktor-faktor Internal & Bobot & Rating & Skor \\
\hline \multicolumn{5}{|c|}{ Kekustan } \\
\hline 1 & $\begin{array}{l}\text { Membuat keripik talas sudah menjadi } \\
\text { budaya/tradisi masyarakat }\end{array}$ & 0.15 & 3 & 0,45 \\
\hline 2 & $\begin{array}{l}\text { Rasa keripik talas yang diprodaks } \\
\text { berbeda (Rasa bulado) }\end{array}$ & 0.20 & 4 & 0.80 \\
\hline 3 & $\begin{array}{l}\text { Pangsa pasar lebih besar di tengah } \\
\text { masyarakat menengah ke bawah }\end{array}$ & 0.10 & 2 & 0.20 \\
\hline 4 & $\begin{array}{l}\text { Modal awal pendinan usaha termasuk } \\
\text { Rinean. }\end{array}$ & 0,10 & 2 & 0,20 \\
\hline 5 & $\begin{array}{l}\text { Peralatan produksi bisa menggunakan } \\
\text { alat yang masih sederhana }\end{array}$ & 0,15 & 3 & 0,45 \\
\hline 6 & $\begin{array}{l}\text { Tersedianya bahan baku yang } \\
\text { memadai. }\end{array}$ & 0.10 & 2 & 0.20 \\
\hline \multicolumn{4}{|c|}{ Jumlah } & 2.30 \\
\hline \multicolumn{5}{|c|}{ Kelemahan } \\
\hline 1 & $\begin{array}{l}\text { Rendahnya kualitas SDM baik untuk } \\
\text { pelaku usaha maupun tenaga kerja. }\end{array}$ & 0.20 & 1 & 0.20 \\
\hline 2 & Modal usaha yang dimiliki terbatas & 0.15 & 2 & 0.30 \\
\hline 3 & $\begin{array}{l}\text { SDM Pengusaha kurang professional } \\
\text { dalam manajemen }\end{array}$ & 0.15 & 2 & 0.30 \\
\hline 4 & $\begin{array}{l}\text { Belum punya daerah pemasann yang } \\
\text { tetap dan strategi yang kurang tepat, } \\
\text { serta kurangnya teknologi modern }\end{array}$ & 0.10 & 3 & 0.30 \\
\hline \multicolumn{4}{|c|}{ Jumlah } & 1.10 \\
\hline
\end{tabular}

Dimana:

$$
\begin{array}{ll}
\mathrm{FC} & =\text { Biaya tetap }(\text { Variabel Cost }) \\
\mathrm{P} & =\text { Harga } \\
\mathrm{VC} & =\text { Biaya variabel perunit } \\
\text { Diket } & =\text { Kapasitas Perhari }=80 \mathrm{bks}
\end{array}
$$$$
\text { Variabel Costs/hari }=5.000
$$$$
\text { Ditanya } \quad=\text { VC Perbungkus ? }
$$

Jawab BEP Unit $=\frac{F C}{p-\frac{V C}{P}}$

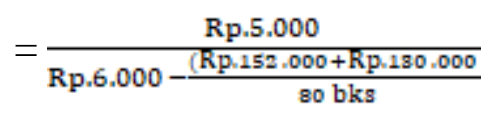

$=\frac{\operatorname{Rp} .5 .000}{\operatorname{Rp} .6 .000-3525}$

$$
\begin{aligned}
& =\frac{\text { Rp.5.000 }}{2475}= \\
& =2,02 \\
& =2 \text { Bungkus }
\end{aligned}
$$

$$
\begin{aligned}
\text { BEP Uang } & =\frac{F C}{1-\frac{V C}{P}} \\
& =\frac{\text { Rp.5000 }}{1-\frac{R p \cdot .582 .000}{R p \cdot 480 \cdot 000}} \\
& =\frac{\text { Rp.5.000 }}{0,425} \\
& =\text { Rp. } 12.121
\end{aligned}
$$

\section{N. Analisa SWOT}

1. Faktor Strategi Internal

Tabel 5 Faktor analisa Internal Pada UKM Top 
(Sumber: Data Olahan Sendiri)

\section{Faktor Strategi Eksternal}

Tabel 6 Faktor analisa Eksternal Pada UKM Top Talasa

\begin{tabular}{|c|c|c|c|c|}
\hline No & Faktor-faktor Eksternal & Bobot & Rating & Skor \\
\hline \multicolumn{5}{|c|}{ Pedaang } \\
\hline 1 & $\begin{array}{l}\text { Merupakan saiah satu makasan pokcok } \\
\text { begi masyankat menengahi bawah }\end{array}$ & 0.15 & 3 & 0.45 \\
\hline 2 & Permintaan Tinggi Untuk Prodak & 0.15 & 3 & 0.45 \\
\hline 3 & Pertumivahas Penduduk & 0.10 & 2 & 0.20 \\
\hline 4 & $\begin{array}{l}\text { Teinologi Pemasaman (pemanfaatan } \\
\text { media sosial) }\end{array}$ & 0.13 & 3 & 0.45 \\
\hline \multicolumn{4}{|c|}{ Jumlah } & 1.55 \\
\hline \multicolumn{5}{|c|}{ Ancaman } \\
\hline 1 & $\begin{array}{l}\text { Saingan prodak dari desa tetangga dan } \\
\text { Kabupaten }\end{array}$ & 0.05 & 4 & 0.20 \\
\hline 2 & $\begin{array}{l}\text { Kualitas Umbi Talas kadang kalah } \\
\text { membuat keripik talas tidak enak }\end{array}$ & 0.05 & 4 & 0.20 \\
\hline 3 & $\begin{array}{l}\text { Modal pesaing lebili besar (lebih } \\
\text { mendukung untuk kspasitas produksi } \\
\text { yang lebih besar) }\end{array}$ & 0.10 & 3 & 0.30 \\
\hline 4 & Iklim usaha belum sepenuhnya koodusif. & 0.10 & 3 & 0.30 \\
\hline \multicolumn{4}{|c|}{ Jumlah } & 2.10 \\
\hline
\end{tabular}

(Sumber: Data Olahan Sendiri)

Dari hasil analisis kekuatan, kelemahan, peluang dan ancaman dari Industri kecil Keripik Talas di Kecamatan Pulaupanggung.

Tabel 7 Matrik Internal-Eksternal

\begin{tabular}{|c|l|l|l|l|}
\hline $\begin{array}{c}\text { N } \\
\text { o }\end{array}$ & \multicolumn{1}{|c|}{ Matrik } & & Skor & $\begin{array}{c}\text { Rata- } \\
\text { rata }\end{array}$ \\
\hline \multirow{2}{*}{1} & \multirow{2}{*}{ Internal } & Kekuatan & 2.30 & \multirow{2}{*}{1.70} \\
\cline { 3 - 4 } & & Kelemahan & 1.10 & \\
\hline \multirow{2}{*}{2} & \multirow{2}{*}{ Ekternal } & Peluang & 1.55 & \multirow{2}{*}{1.83} \\
\cline { 3 - 4 } & & Ancaman & 2.10 & \\
\hline
\end{tabular}

(Sumber: Data Olahan Sendiri)

Apabila digambarkan adalah sebagai berikut Total Nilai IFE Yang Diberi Bobot

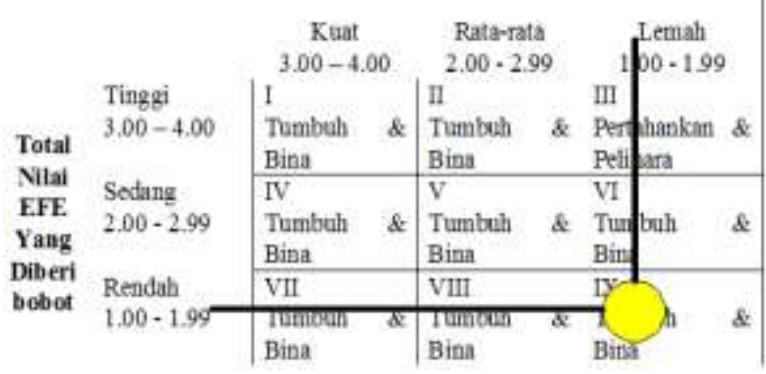

(Sumber: Data Olahan Sendiri)

Gambar 7 Matrik Internal dan Eksternal

\section{N. Matrik SWOT}

SWOT adalah akronim untuk kekuatan (Strenghts), kelemahan (Weakness), peluang (Opportunities), dan ancaman (Threats) dari lingkungan eksternal perusahaan. Menurut David (Fred R. David, 2008,8), Semua organisasi memiliki kekuatan dan kelemahan dalam area fungsional bisnis. Tidak ada perusahaan yang sama kuatnya atau lemahnya dalam semua area bisnis.

\section{Tabel 8 Matrik SWOT}

\begin{tabular}{|c|c|c|}
\hline & $\begin{array}{l}\text { STRENGTH (S) } \\
\text { 1. Memboat keripik talas } \\
\text { sudah menjadii } \\
\text { budayatradis } \\
\text { masyarakat } \\
\text { 2. Rasa keripik tal as yang } \\
\text { diproduksi berbeda } \\
\text { (Rasa balado) } \\
\text { 3. Pangsa pasar lebah } \\
\text { besar di tengah } \\
\text { masyarakat menengah } \\
\text { ke bawah } \\
\text { 4. Modal nwal pendirian } \\
\text { usaha tennasuk } \\
\text { Ringan. } \\
\text { 5. Peralatnn produksi bisa } \\
\text { menggualkan alat } \\
\text { yang masih sedertana } \\
\text { 6. Tersedanya bahas } \\
\text { baku yang memadai. }\end{array}$ & $\begin{array}{l}\text { WEAKVESS (W) } \\
\text { 1. Rendahnya kuahitas } \\
\text { SDM baik untak } \\
\text { pelaks usaha maupun } \\
\text { tenaga kerja. } \\
\text { 2. Modal usaha yang } \\
\text { dimiliki terbatas } \\
\text { 3. SDM Pengusaha } \\
\text { kurang professiceal } \\
\text { dalam manajemen } \\
\text { 4. Belumi punya daerah } \\
\text { pemasaran yang tetap } \\
\text { dan srategi yamg } \\
\text { kurang tepat, serta } \\
\text { kurangrya telmodogi } \\
\text { modem }\end{array}$ \\
\hline $\begin{array}{l}\text { OPPRTUNTTES (O) } \\
\text { 1. Merupakan salah satu } \\
\text { makanan pokok bagi } \\
\text { masyarakat menengah } \\
\text { bowah } \\
\text { 2. Permintann Tinggi } \\
\text { Untuk Produk } \\
\text { 3. Pertumbuban } \\
\text { penduduk } \\
\text { 4. Teknologi Pemasaran }\end{array}$ & $\begin{array}{l}\text { Strategi so } \\
\text { 1. Memperluas daerah } \\
\text { distribusi dengan } \\
\text { membuka juringan d } \\
\text { luar daeral } \\
\text { 2. Meminfaatkan pangsa } \\
\text { pasar dengan adanya } \\
\text { teknologi modem } \\
\text { 3. Mempertahaskan } \\
\text { kualitas produk untuk } \\
\text { tetap merjaga } \\
\text { permintaan yang tingal }\end{array}$ & $\begin{array}{l}\quad \text { Strategi wo } \\
\text { 1. Meningkaflan Kualitas } \\
\text { SDM } \\
\text { 2. Meningkatikan doerah } \\
\text { penuseran dengan } \\
\text { menggunakan } \\
\text { teknologi yang ada } \\
\text { melalui berbagai media }\end{array}$ \\
\hline $\begin{array}{l}\text { THRE.ATS (T) } \\
\text { 1. Saingan produk dari } \\
\text { desa tetangea dan } \\
\text { Kabupaten } \\
\text { 2. Kualitas Unabi Tal Bs } \\
\text { kadnng kalah } \\
\text { trembuat keripik talas, } \\
\text { tidak enak. }\end{array}$ & $\begin{array}{l}\text { Strat egi ST } \\
\text { 1. Mempertahankan } \\
\text { kualitas yang ada } \\
\text { dengan hargs } \\
\text { terjangkau } \\
\text { 2. Melakukan inovasi } \\
\text { produk beik, rasa } \\
\text { manpun kemasan } \\
\text { dengan } \\
\text { mempertahaskan } \\
\text { kualitas yang ada. }\end{array}$ & $\begin{array}{l}\text { Strategi WT } \\
\text { 1. Menjaga kualitas } \\
\text { produk } \\
\text { 2. Penambahan modal / } \\
\text { investas } \\
\text { 3. Meningkatkan volume } \\
\text { produks yang ada. }\end{array}$ \\
\hline
\end{tabular}

(Sumber: Data Olahan Sendiri)

\section{KESIMPULAN}

Berdasarkan data yang telah dilakukan, di lapangan kesimpulan yang di ambil setelah melakukan Penelitian Tugas Akhir adalah sebagai berikut.

1. Biaya bahan baku Rp. 152.000, Biaya tenaga kerja Rp. 130.000, biaya biaya Front Of Hose (FOH) Rp. 31.950 dan investasi barang atau alat Rp. 1.375.000.

2. Break Even Point (Titik Impas) Unit dari usaha keripik olahan talas yang di desa Tekad 
Lampung Yaitu 2 bungkus, Sedangkan Untuk BEP uang yang didapat yaitu Rp. 12.121.

3. Stratregi pemasaran yang tepat untuk usaha keripik olahan talas di desa Tekad Lampung dengan metode SWOT, yaitu:

a. Memperluas daerah distribusi dengan membuka jaringan di luar daerah.

b. Memanfaatkan pangsa pasar dengan adanya teknologi modern seperti Line, Facebook. Instagram, Path, Twiter

c. Mempertahan kualitas produk untuk tetap menjaga permintaan yang tinggi.

\section{DAFTAR PUSTAKA}

Abdullah, Thamrin, Francis Tantri, 2012. Manjajemen Pemasaran. Jakarta; Raja Grafindo Perkasa.

Badan Pusat Statistik, Tanggamus Dalam Angka 2014, Lampung: BPS Kabupaten

Tanggamus, 2014

Badan Pusat Statistik Republik Indonesia. (2014). bps.go.id. [Diakses tanggal 15 April 2014]

Ermayuli, Hanung Ismono, Sri Setyani. (2011). Analisis Teknik dan Finansial Agroindustri Skala Kecil pada Berbagai Proses Pembuatan Keripik Talas di Kabupaten Lampung Barat. J. Teknologi dan Industri Hasil Pertanian: 16 (1): 82-90.

Fajar Nur'aini Dwi Farimah (2016), Teknik Analisis SWOT, Yogyakarta; Quadrant.

Himatul Miftah, A. Syarbaini, TC Andari, 2012. Analisis Pendapatan dan Nilai Tambah Ubi Kayu sebagai penyusun Model Pola Klaster. J. Pertanian: 3 (1): 50-58.

Nurmayani, Hukum Administrasi Daerah, Bandar Lampung: Penerbit Universitas Lampung, 2009.

Payaman J. Simanjuntak, (2001), Pengantar Ekonomi Sumber Daya Manusia Edisi 2001, Jakarta: FE UI.

Rangkuni, F. (2006). Analisis SWOT Teknik Membedah Kasus Bisnis. Jakarta; Gramedia Pustaka Utama

Rangkuni, F. (2012). SWOT Balanced Scorecard, Tekni Menyusun Strategi
Koporat yang Efektif Plus Cara Mengelola Kinerja dan Resiko. Jakarta; Gramedia Pustaka Utama

Silvana Maulidah dan Fenny Kusumawardani. 2011. Nilai tambah Agroindustri Belimbing Manis (Averrhoa Carambola L.) dan Optimalisasi Output sebagai Upaya Peningkatan Pendapatan. J. AGRISE: XI (1) : 1412-1425.

Sopiah, Etta Mamang Sangadji. 2013. Perilaku Kpnsumen Pendekatan Praktis Disertai Himpunan Jurnal Penelitian. Andi; Jakarta

Wulandari, B.E., Harlita dan Muzzayinah., (2011). Identifikasi fungsi dalam tape talas (colacasia escukulenta). Jurnal SMA Al Islam 1, Surakarta.Vol 1 no 1 65-67. 